\title{
Figure-ground organization in real and subjective contours: A new ambiguous figure, some novel measures of ambiguity, and apparent distance across regions of figure and ground
}

\author{
MATTHEW D. SHANK and JAMES T. WALKER \\ University of Missouri-St. Louis, St. Louis, Missouri
}

\begin{abstract}
This study was designed to assess the effects of organization, luminance contrast, sector angle, and orientation on a new, highly ambiguous Cs-keyhole figure. Organization and contrast were the most important factors, and sector angle also influenced figure-ground relationships. There was no significant effect of orientation, nor was there any significant interaction between any of the factors. Several new measures of figure-ground organization were developed, such as ambiguity ratios based on reaction times and on ratings of the strength of perceived organizations, providing new quantitative measures of figure-ground relationships. Distances measured across figural regions appeared smaller than equal distances across the ground in the new reversible figure, and also in Rubin's classic vase-face figure presented in real and subjective contours. Inducing a perceptual set to see a particular organization in a reversible figure influenced the apparent distance across that organization. Several possible explanations of the observed effects are considered: (1) an instance of Emmert's law, based on the difference in apparent depth of figure and ground; (2) an aspect of the Müller-Lyer illusion; (3) a feature-detector model of contour attraction; (4) a natural set or predisposition to see a figure as smaller; and (5) framing effects. The first two explanations appear the most promising.
\end{abstract}

Figure-ground organization is defined as the process whereby stimuli are selected and perceived as figures against a ground or background (Gerow, 1986), or, alternatively, as the tendency to see parts of a scene as solid, well-defined objects standing out against a less distinctive background (Sekuler \& Blake, 1985). Considering the vast amount of stimulus information impinging upon us, figure-ground organization is useful in making sense of the world, in helping differentiate important from unimportant stimuli.

The systematic study of figure-ground organization dates from the early work of Edgar Rubin (1921/1958). Rubin believed that the fundamental unit of form perception consisted of a figure standing on a background, and furthermore, that the central, most important aspect of the perception of an object lay in experiencing the figure.

Rubin attempted to isolate some of the characteristics that distinguish a figure from the ground. First, the figure and ground do not share the attribute of shape-that is, what is seen as figure has a shape, while the ground is relatively formless. Second, the figure has somewhat the character of a "thing," whereas the ground is more like

This paper is based on Matthew D. Shank's dissertation, which was supervised by James $T$. Walker. The dissertation was submitted to the University of Missouri-St. Louis in partial fulfillment of the requirements for the PhD. Reprint requests should be addressed to James $T$. Walker, Department of Psychology, University of Missouri-St. Louis, St. Louis, MO 63121 a "substance." Figure and ground also differ in apparent localization, the figure usually appearing closer to the observer than the background. Finally, the figure is more impressive, more dominant, better remembered, and more apt to suggest meaning than the ground is.

A number of personal factors and stimulus variables have been found to influence figure-ground organization. Several personal factors have been examined, such as affect (Harrower, 1936; Rubin, 1921/1958), meaningfulness (Zusne, 1970), past expectations (Epstein \& De Shazo, 1961; Epstein \& Rock, 1960), and motivation (Ayllon \& Sommer, 1956; Schafer \& Murphy, 1943; D. E. P. Smith \& Hochberg, 1954). Many stimulus variables have been systematically manipulated, such as brightness (Lindauer \& Lindauer, 1970; Oyama, 1960; Wever, 1927), hue (Oyama, 1960; Rubin, 1921/1958), motion (Regan \& Beverley, 1984), spatial frequency (Klymenko \& Weisstein, 1986; Weitzman, 1963), orientation (Oyama, 1960; Zusne, 1970), area (Harrower, 1936; Koffka, 1935; Oyama, 1960), and texture (Julesz, 1975, 1978, 1981).

The present study was designed to assess the effects of four stimulus factors on the strength and ambiguity of figure-ground organization in a new reversible figure. The top panel of Figure 1 shows the three organizations of this figure, the $C s$, keyhole, and ambiguous organizations. This new figure, and the nature of the stimulus variables that were manipulated, are described in detail in a later section. In addition, some novel measures of figure-ground organization were developed. 


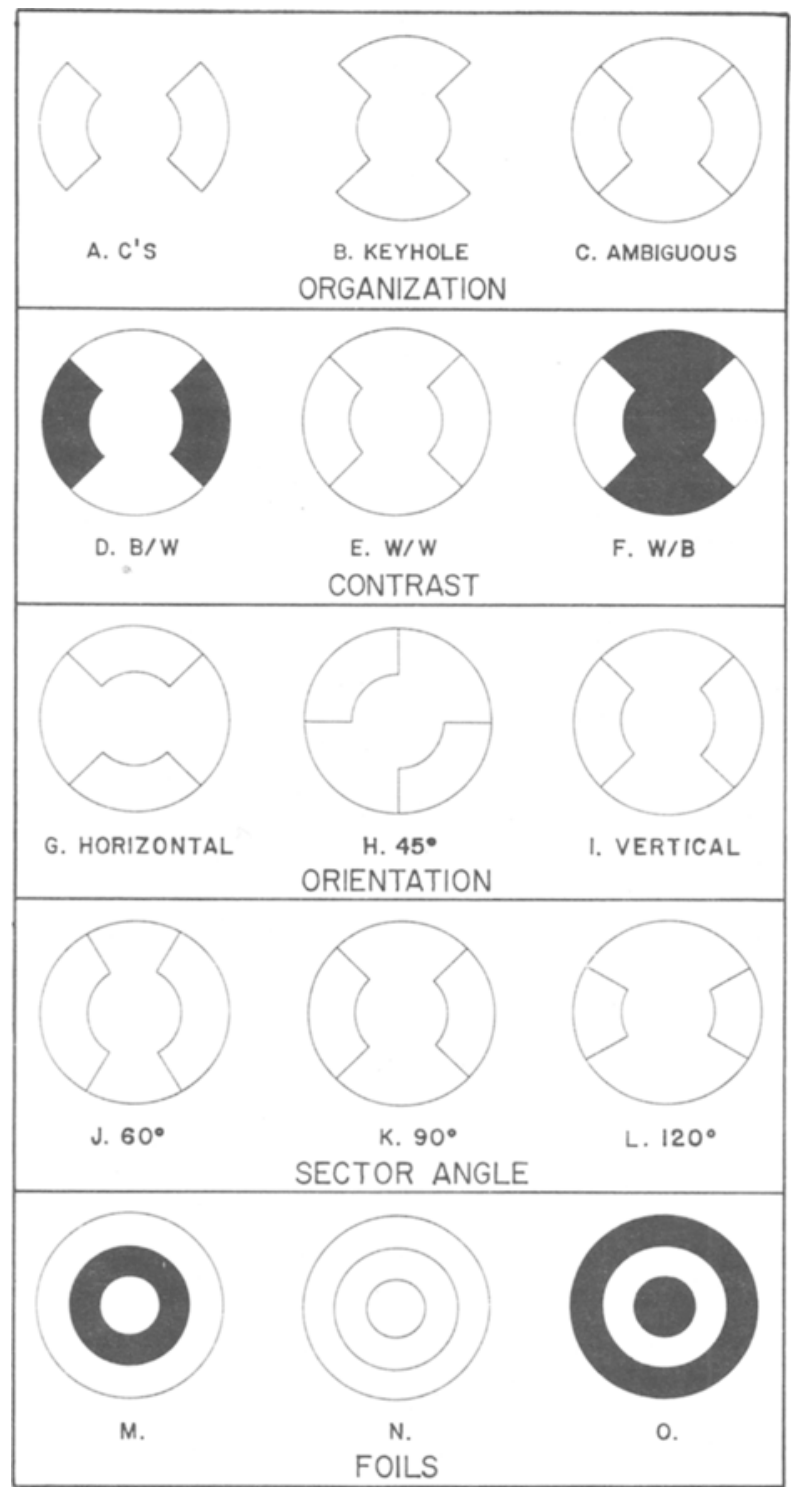

Figure 1. Examples of stimuli in Experiment 1. Four factors were manipulated, each having three levels. Bottom panel shows the three foils.

\section{EXPERIMENT 1}

Experiment 1 was conducted to assess the strength and ambiguity of several versions of a new reversible figure, using reaction times, rating-scale measures, number of reversals observed in 30-sec trials, and duration of each perceived organization.

\section{Method}

Subjects. Twenty-seven male and 27 female undergraduate psychology students at the University of Missouri-St. Louis received extra course credit for participating in this experiment. Their ages ranged from 18 to 38 , and the mean age was 20.63 .

Stimuli and Apparatus. The reversible figures were $10 \mathrm{~cm}$ in diameter and were presented inside a $12-\mathrm{cm}$ aperture in a black sur- round. The stimuli were shown in a two-channel Gerbrands tachistoscope, Model T-1C-3, at a viewing distance of $57 \mathrm{~cm}$, so each stimulus subtended a visual angle of $10^{\circ}$. The white and black portions of the stimuli had luminances of 19.2 and $2.0 \mathrm{~cd} / \mathrm{m}^{2}$, respectively. In the fixation fields (described in the Procedure section), the white portions of the displays had a luminance of $19.0 \mathrm{~cd} / \mathrm{m}^{2}$.

The factors of organization, luminance contrast, orientation, and sector angle were manipulated in a full factorial design with three levels of each factor. Organization and luminance contrast were within-subjects factors, while sector angle and orientation were between-subjects factors. Thus, each subject viewed nine test stimuli combining the three levels of the organization and luminance-contrast factors.

The organization factor was manipulated with the presentation of unambiguous Cs, unambiguous keyholes, and ambiguous figures showing both organizations, as in Figures 1A, 1B, and 1C. There were three levels of luminance contrast between the two organizations: black $\mathrm{Cs}$ and white keyhole (B/W), white $\mathrm{Cs}$ and white keyhole $(\mathrm{W} / \mathrm{W})$, and white $\mathrm{Cs}$ and black keyhole (W/B), as in Figures $1 D, 1 E$, and $1 F$. Orientation was manipulated by presenting the keyhole horizontally, inclined $45^{\circ}$, and vertically, as in Figures $1 \mathrm{G}, 1 \mathrm{H}$, and 11. Sector angles of $60^{\circ}, 90^{\circ}$, and $120^{\circ}-$ defined with respect to the keyhole organization-are illustrated in Figures $1 \mathrm{~J}, 1 \mathrm{~K}$, and $1 \mathrm{~L}$.

Three foils (see Figures $1 \mathrm{M}, 1 \mathrm{~N}$, and 10 ) consisted of black and white concentric circles, so neither the Cs nor the keyhole organization could be seen in the foils. During measurement of the reaction times, the foils were interspersed among the test stimuli to guard against the possibility that the subjects might react merely to the onset of a stimulus field, as opposed to the particular organization seen first in a test stimulus. In fact, no subject reacted to a foil.

Procedure. To familiarize the subjects with the apparatus, practice trials were given with four displays that contained the following stimuli: (1) an L only; (2) an R only; (3) a combined $L$ and $R$; and (4) an $X$, a display containing neither an $L$ nor an $R$ (see Figure 2 , top). If the subject saw only an $L$, or only an $R$, then the subject was instructed to respond as quickly as possible by moving a horizontal lever to the left, or to the right, using the preferred hand. If both an $\mathrm{L}$ and an $\mathrm{R}$ were observed in the same display, then the subject was told to respond to the letter that was seen first by moving the lever in that direction, and to respond to the other letter as soon as it was seen by moving the lever in the other direction. Finally, the subject was told to make no response to a display containing neither an $L$ nor an $R$. The four practice trials were presented in the fixed order of $L, R$, combined $L$ and $R$, and $X$.

Each practice trial began with the subject's viewing a red dot in the center of a fixation field with arrows pointing to an $L$ on the left and an $\mathbf{R}$ on the right to remind the subject of the appropriate responses (see Figure 2, bottom). The subject pushed a button with the nonpreferred hand to activate the practice stimulus. Each stimulus was exposed for a maximum of $5 \mathrm{sec}$, at which time the trial was terminated and the fixation field returned.

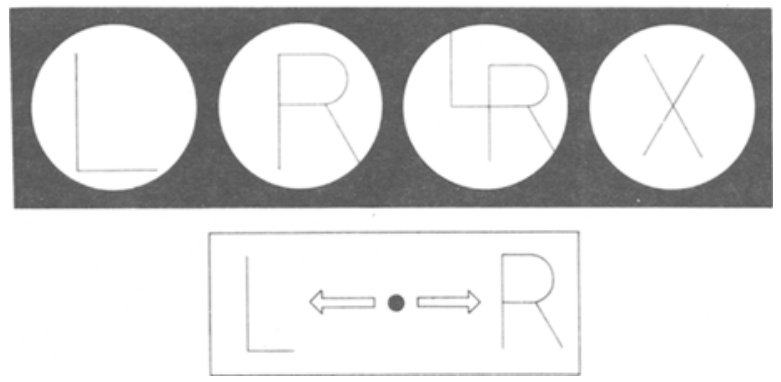

Figure 2. Top: Practice stimuli. Bottom: Fixation field. 

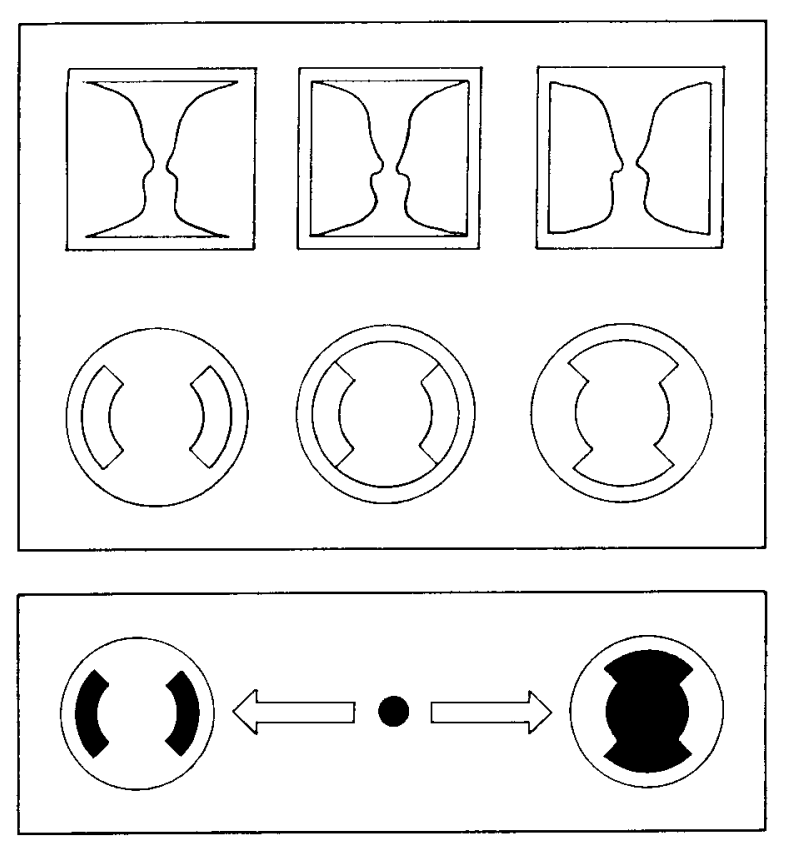

Figure 3. Top panel: Demonstration figures. Bottom panel: Fixation field.

To familiarize the subjects with the concept of figure-ground organization, the display in Figure 3 (top panel) was shown. This display showed the classic vase-face figure in three organizations (vase, ambiguous, faces) and the Cs-keyhole figure in its three organizations (Cs, ambiguous, keyhole).

In the experiment proper, the fixation field shown in the bottom panel of Figure 3 was presented. The left-right locations of the Cs and keyhole in this fixation field were counterbalanced between subjects, corresponding to the left-right assignment of the lever responses to those perceived organizations. The subject was instructed to respond as quickly as possible by moving the lever to the left (right) if only the Cs were seen, or to the right (left) if only the keyhole was seen. The subject was then told that several stimuli containing both the $\mathrm{Cs}$ and the keyhole organizations would be presented. In these cases, the subject was to respond to the figure that was seen first, by moving the lever in the appropriate direction; if the other figure was then seen, the subject was to move the lever as quickly as possible in the other direction. Finally, the subject was told that in some trials neither the Cs nor the keyhole would appear, in which case no response should be made. The subjects were reminded to make all responses as quickly and as accurately as possible.

As in the practice trials, the subject initiated each presentation of a test stimulus by pushing a button with the nonpreferred hand. If the subject responded only to one organization, or made no response at all, then the test stimulus was exposed for a maximum of $5 \mathrm{sec}$. If the subject responded to both organizations within $5 \mathrm{sec}$, the second response terminated the test stimulus and restored the fixation field.

Nine test stimuli and the three foils were shown to each subject in an individually randomized sequence, and then in a reversal of that order, thus totaling 24 trials. If a subject made an incorrect response to an unambiguous $\mathrm{Cs}$ or keyhole figure, then that response was discarded and the stimulus was readministered at a later point in the sequence. No subject made more than two such errors.

After the reaction times were all measured, the subject rated the strength of the Cs and keyhole regions of the figures, using a scale of zero to 10 . A rating approaching 10 indicated a strong figural region, whereas a rating approaching zero indicated a weak or nonexistent figure. All trials were terminated after the subject rated each organization, or after a maximum of $15 \mathrm{sec}$. The sequence of the nine test stimuli was randomized individually for each subject, and so was the sequence of organizations judged (Cs or keyhole) for each stimulus.

Figure-ground reversibility and the perceived duration of each organization were then assessed. The stimuli were shown to each subject in an individually randomized sequence. The subjects were instructed to move the lever switch to indicate the perceived organization of the stimulus (Cs or keyhole) and the duration of that organization. For example, if the subject first saw the $\mathrm{Cs}$ as figure, then the subject was instructed to respond by moving the lever to the left (or right), holding it in that position as long as that organization was seen. If the subject then saw the keyhole as figure, the subject was to move the lever to the right (or left), holding it there as long as the keyhole organization was seen. If the Cs organization was perceived again, the subject was to move the lever back to the left (or right), holding it there as long as that organization was seen-and so on for the duration of each 30 -sec trial. The total number of reversals and the total perceived duration for each organization were recorded automatically.

\section{Results and Discussion}

Several indices were developed to assess the strength and ambiguity of the Cs-keyhole stimulus. The ambiguity ratio for response speed was determined with the following equation:

$$
\mathrm{ASP}=(C-K) /(C+K),
$$

where ASP = ambiguity ratio for response speed, $C=$ response speed of the Cs organization, and $K=$ response speed of the keyhole organization.

Response speeds, the reciprocals of reaction times, were utilized in the above equation, because in some stimuli one of the possible organizations was never seen, and would therefore have had an infinite reaction time. Response speeds were determined by averaging the two trials for each stimulus. The ambiguity ratio for response speed had a possible range of -1 to +1 , where -1 indicates the strongest possible keyhole figure, +1 indicates the strongest possible Cs figure, and zero indicates a completely ambiguous figure.

Using Equation 1, ambiguity ratios were also determined for ratings (ARAT), where $C$ and $K$ were, respectively, the ratings of the Cs and keyhole organizations, and for durations (ADUR), where $C$ and $K$ were the perceived durations of the two organizations. Each ambiguity ratio represents the contrast between the response speed, ratings, or perceived duration of the two organizations in each figure, and thus constitutes a measure comparable to the Michelson contrast ratio for luminance.

Table 1 shows the means of the raw scores and derived measures for each level of the four factors. A four-way mixed-design analysis of variance was calculated for each of the ambiguity ratios (ASP, ARAT, ADUR) and for the total number of reversals (REV). For each ANOVA, organization (Cs, ambiguous, keyhole) and luminance contrast (B/W, W/W, W/B) were within-subjects factors, and orientation (horizontal, $45^{\circ}$, vertical) and sector angle 
Table 1

Raw Scores and Derived Measures in Experiment 1

\begin{tabular}{|c|c|c|c|c|c|c|c|c|c|c|c|c|c|c|}
\hline & & & \multicolumn{3}{|c|}{ Organization } & \multicolumn{3}{|c|}{ Contrast } & \multicolumn{3}{|c|}{ Orientation } & \multicolumn{3}{|c|}{ Sector angle } \\
\hline & & & $\mathrm{Cs}$ & Ambig & Key & $\mathrm{B} / \mathrm{W}$ & $\mathbf{W} / \mathbf{W}$ & $\mathrm{W} / \mathrm{B}$ & $\mathbf{H}$ & 45 & $\mathrm{~V}$ & 60 & 90 & 120 \\
\hline \multirow{2}{*}{$\begin{array}{l}\text { Reaction } \\
\text { time (sec) }\end{array}$} & Cs & $\begin{array}{l}\text { Mean } \\
S D\end{array}$ & $\begin{array}{l}.86 \\
.22\end{array}$ & $\begin{array}{r}1.39 \\
.57\end{array}$ & $\begin{array}{r}4.29 \\
.95\end{array}$ & $\begin{array}{r}2.17 \\
.54\end{array}$ & $\begin{array}{r}2.14 \\
.50\end{array}$ & $\begin{array}{r}2.22 \\
.47\end{array}$ & $\begin{array}{r}2.32 \\
.36\end{array}$ & $\begin{array}{r}2.00 \\
.49\end{array}$ & $\begin{array}{r}2.21 \\
.26\end{array}$ & $\begin{array}{r}2.19 \\
.30\end{array}$ & $\begin{array}{r}2.15 \\
.43\end{array}$ & $\begin{array}{r}2.20 \\
.46\end{array}$ \\
\hline & Keyhole & $\begin{array}{l}\text { Mean } \\
S D\end{array}$ & $\begin{array}{l}4.18 \\
1.07\end{array}$ & $\begin{array}{r}1.46 \\
.51\end{array}$ & $\begin{array}{l}.88 \\
.30\end{array}$ & $\begin{array}{r}2.08 \\
.52\end{array}$ & $\begin{array}{r}2.35 \\
.49\end{array}$ & $\begin{array}{r}2.10 \\
.59\end{array}$ & $\begin{array}{r}2.26 \\
.36\end{array}$ & $\begin{array}{r}2.04 \\
.57\end{array}$ & $\begin{array}{r}2.22 \\
.30\end{array}$ & $\begin{array}{r}1.95 \\
.47\end{array}$ & $\begin{array}{r}2.28 \\
.31\end{array}$ & $\begin{array}{r}2.29 \\
.43\end{array}$ \\
\hline \multirow{2}{*}{$\begin{array}{l}\text { Response } \\
\text { speed (1/RT) }\end{array}$} & $\mathrm{Cs}$ & $\begin{array}{l}\text { Mean } \\
S D\end{array}$ & $\begin{array}{r}1.31 \\
.27\end{array}$ & $\begin{array}{l}.98 \\
.31\end{array}$ & $\begin{array}{l}.17 \\
.25\end{array}$ & $\begin{array}{l}.80 \\
.23\end{array}$ & $\begin{array}{l}.85 \\
.26\end{array}$ & $\begin{array}{l}.82 \\
.22\end{array}$ & $\begin{array}{l}.77 \\
.24\end{array}$ & $\begin{array}{l}.88 \\
.20\end{array}$ & $\begin{array}{l}.83 \\
.18\end{array}$ & $\begin{array}{l}.82 \\
.21\end{array}$ & $\begin{array}{l}.87 \\
.21\end{array}$ & $\begin{array}{l}.77 \\
.21\end{array}$ \\
\hline & Keyhole & $\begin{array}{l}\text { Mean } \\
S D\end{array}$ & $\begin{array}{l}.19 \\
.25\end{array}$ & $\begin{array}{l}.91 \\
.24\end{array}$ & $\begin{array}{r}1.32 \\
.31\end{array}$ & $\begin{array}{l}.87 \\
.21\end{array}$ & $\begin{array}{l}.72 \\
.21\end{array}$ & $\begin{array}{l}.82 \\
.26\end{array}$ & $\begin{array}{l}.76 \\
.22\end{array}$ & $\begin{array}{l}.84 \\
.18\end{array}$ & $\begin{array}{l}.82 \\
.18\end{array}$ & $\begin{array}{l}.86 \\
.23\end{array}$ & $\begin{array}{l}.80 \\
.18\end{array}$ & $\begin{array}{l}.75 \\
.17\end{array}$ \\
\hline $\begin{array}{l}\text { Ambiguity ratio } \\
\text { for speed }\end{array}$ & & $\begin{array}{l}\text { Mean } \\
S D\end{array}$ & $\begin{array}{l}.80 \\
.26\end{array}$ & $\begin{array}{l}.03 \\
.16\end{array}$ & $\begin{array}{r}-.81 \\
.25\end{array}$ & $\begin{array}{r}-.03 \\
.15\end{array}$ & $\begin{array}{l}.06 \\
.16\end{array}$ & $\begin{array}{r}-.01 \\
.15\end{array}$ & $\begin{array}{l}.00 \\
.11\end{array}$ & $\begin{array}{l}.01 \\
.11\end{array}$ & $\begin{array}{l}.01 \\
.10\end{array}$ & $\begin{array}{r}-.04 \\
.10\end{array}$ & $\begin{array}{l}.04 \\
.11\end{array}$ & $\begin{array}{l}.03 \\
.10\end{array}$ \\
\hline \multirow{2}{*}{$\begin{array}{l}\text { Rating scale } \\
(0-10)\end{array}$} & $\mathrm{Cs}$ & $\begin{array}{l}\text { Mean } \\
\text { SD }\end{array}$ & $\begin{array}{l}8.71 \\
1.37\end{array}$ & $\begin{array}{l}7.38 \\
1.56\end{array}$ & $\begin{array}{l}1.41 \\
1.48\end{array}$ & $\begin{array}{l}5.98 \\
1.27\end{array}$ & $\begin{array}{l}5.15 \\
1.27\end{array}$ & $\begin{array}{l}6.38 \\
1.08\end{array}$ & $\begin{array}{r}6.24 \\
.61\end{array}$ & $\begin{array}{r}5.85 \\
.88 \\
\end{array}$ & $\begin{array}{l}5.41 \\
1.07\end{array}$ & $\begin{array}{r}5.64 \\
.93\end{array}$ & $\begin{array}{l}5.81 \\
1.03\end{array}$ & $\begin{array}{r}6.06 \\
.80\end{array}$ \\
\hline & Keyhole & $\begin{array}{l}\text { Mean } \\
S D\end{array}$ & $\begin{array}{l}1.93 \\
2.07\end{array}$ & $\begin{array}{l}7.43 \\
1.58\end{array}$ & $\begin{array}{l}8.92 \\
1.18\end{array}$ & $\begin{array}{l}6.88 \\
1.16\end{array}$ & $\begin{array}{l}5.09 \\
1.57\end{array}$ & $\begin{array}{l}6.31 \\
1.36 \\
\end{array}$ & $\begin{array}{r}6.25 \\
.85\end{array}$ & $\begin{array}{l}6.19 \\
1.45\end{array}$ & $\begin{array}{l}5.83 \\
1.78 \\
\end{array}$ & $\begin{array}{l}6.30 \\
1.41 \\
\end{array}$ & $\begin{array}{l}6.09 \\
1.24 \\
\end{array}$ & $\begin{array}{r}5.90 \\
.84 \\
\end{array}$ \\
\hline $\begin{array}{l}\text { Ambiguity ratio } \\
\text { for ratings }\end{array}$ & & $\begin{array}{l}\text { Mean } \\
S D\end{array}$ & $\begin{array}{l}.69 \\
.30\end{array}$ & $\begin{array}{l}.01 \\
.12\end{array}$ & $\begin{array}{r}-.76 \\
.23\end{array}$ & $\begin{array}{r}-.06 \\
.14\end{array}$ & $\begin{array}{l}.03 \\
.14\end{array}$ & $\begin{array}{r}-.02 \\
.13\end{array}$ & $\begin{array}{l}.00 \\
.11\end{array}$ & $\begin{array}{r}-.02 \\
.11\end{array}$ & $\begin{array}{r}-.04 \\
.11\end{array}$ & $\begin{array}{r}-.07 \\
.11\end{array}$ & $\begin{array}{r}-.03 \\
.06\end{array}$ & $\begin{array}{l}.04 \\
.11\end{array}$ \\
\hline $\begin{array}{l}\text { Reversals } \\
\text { (in } 30 \mathrm{sec} \text { ) }\end{array}$ & & $\begin{array}{l}\text { Mean } \\
S D\end{array}$ & $\begin{array}{l}4.64 \\
6.01\end{array}$ & $\begin{array}{l}14.04 \\
11.34\end{array}$ & $\begin{array}{l}3.51 \\
3.51\end{array}$ & $\begin{array}{l}7.41 \\
5.59\end{array}$ & $\begin{array}{l}7.33 \\
5.60\end{array}$ & $\begin{array}{l}7.45 \\
6.19\end{array}$ & $\begin{array}{l}8.03 \\
6.17\end{array}$ & $\begin{array}{l}8.38 \\
6.44\end{array}$ & $\begin{array}{l}5.78 \\
3.51\end{array}$ & $\begin{array}{l}8.65 \\
6.99\end{array}$ & $\begin{array}{l}5.53 \\
3.39\end{array}$ & $\begin{array}{l}8.01 \\
5.47\end{array}$ \\
\hline \multirow{2}{*}{$\begin{array}{l}\text { Duration } \\
\text { (in } 30 \mathrm{sec} \text { ) }\end{array}$} & Cs & $\begin{array}{l}\text { Mean } \\
\text { SD }\end{array}$ & $\begin{array}{r}24.61 \\
5.13\end{array}$ & $\begin{array}{r}12.31 \\
2.11\end{array}$ & $\begin{array}{l}2.08 \\
2.86\end{array}$ & $\begin{array}{r}12.61 \\
2.25\end{array}$ & $\begin{array}{r}13.18 \\
2.05\end{array}$ & $\begin{array}{r}13.21 \\
2.98\end{array}$ & $\begin{array}{r}12.79 \\
1.95\end{array}$ & $\begin{array}{r}12.55 \\
1.81\end{array}$ & $\begin{array}{r}13.64 \\
1.48\end{array}$ & $\begin{array}{r}12.33 \\
1.61\end{array}$ & $\begin{array}{r}12.82 \\
1.76\end{array}$ & $\begin{array}{r}13.83 \\
1.74\end{array}$ \\
\hline & Keyhole & $\begin{array}{l}\text { Mean } \\
S D \\
\end{array}$ & $\begin{array}{l}3.27 \\
4.05\end{array}$ & $\begin{array}{r}13.86 \\
2.59\end{array}$ & $\begin{array}{r}25.96 \\
3.89\end{array}$ & $\begin{array}{r}14.81 \\
2.44\end{array}$ & $\begin{array}{r}14.14 \\
1.73\end{array}$ & $\begin{array}{r}14.14 \\
2.81 \\
\end{array}$ & $\begin{array}{r}14.43 \\
2.06 \\
\end{array}$ & $\begin{array}{r}14.30 \\
1.72 \\
\end{array}$ & $\begin{array}{r}14.36 \\
1.46\end{array}$ & $\begin{array}{r}15.13 \\
1.35\end{array}$ & $\begin{array}{r}14.91 \\
1.56\end{array}$ & $\begin{array}{r}13.05 \\
1.53\end{array}$ \\
\hline $\begin{array}{l}\text { Ambiguity ratio } \\
\text { for duration }\end{array}$ & & $\begin{array}{l}\text { Mean } \\
S D\end{array}$ & $\begin{array}{l}.75 \\
.31\end{array}$ & $\begin{array}{r}-.06 \\
.15\end{array}$ & $\begin{array}{r}-.84 \\
.22\end{array}$ & $\begin{array}{r}-.08 \\
.15\end{array}$ & $\begin{array}{r}-.04 \\
.12\end{array}$ & $\begin{array}{r}-.03 \\
.19\end{array}$ & $\begin{array}{r}-.06 \\
.13\end{array}$ & $\begin{array}{r}-.06 \\
.10\end{array}$ & $\begin{array}{r}-.03 \\
.10\end{array}$ & $\begin{array}{r}-.10 \\
.09\end{array}$ & $\begin{array}{r}-.07 \\
.11\end{array}$ & $\begin{array}{l}.02 \\
.09\end{array}$ \\
\hline
\end{tabular}

$\left(60^{\circ}, 90^{\circ}, 120^{\circ}\right)$ were between-subjects factors. There were six subjects ( 3 males and 3 females) at each combination of the three levels of orientation and sector angle.

The ambiguity ratio for response speeds showed a highly significant effect for the organization factor $[F(2,90)=595.54, p<.001]$, and Newman-Keuls tests showed that all differences between levels of the factor were significant $(p<.05)$. The contrast factor was also significant $[F(2,90)=6.71, p<.001]$, the $\mathrm{W} / \mathrm{W}$ level differing from the B/W and W/B levels $(p<.05)$. Sector angle also produced a significant effect $[F(2,45)=$
$3.60, p<.05]$. Orientation produced no significant effect $(F<1)$, nor were there any significant interactions. Figure 4A shows the ambiguity ratios for response speeds for each factor.

The ambiguity ratio for the rating scale showed similar results (see Figure 4B). The factors of organization and contrast were highly significant $[F(2,90)=425.09$ and 9.74, respectively, $p<.001]$. Sector angle was also significant $[F(2,45)=5.54, p<.001]$. Newman-Keuls tests showed all levels of organization and contrast to differ from each other $(p<.05)$, and the $120^{\circ}$ angle to
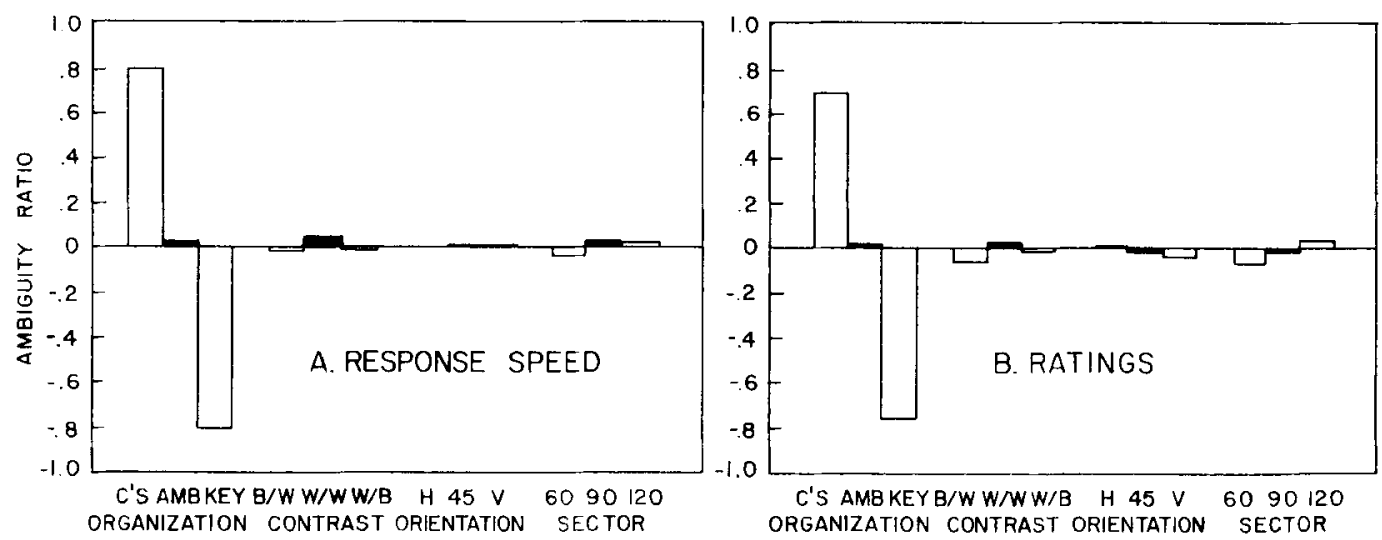

Figure 4. Ambiguity ratios for response speed and ratings in Experiment 1. 
differ from the $60^{\circ}$ and $90^{\circ}$ sector angles $(p<.05)$. Orientation was not significant, nor were any interactions $(F<1)$.

The ambiguity ratio for duration of organizations (see Table 1) showed significant effects of organization and sector angle $[F(2,90)=570.66, p<.001$, and $F(2,45)=$ $7.93, p<.001$, respectively]. The effect of contrast was not significant $[F(2,90)=2.58, p<.08]$, nor was the effect of orientation $(F<1)$. Newman-Keuls tests showed significant differences between all levels of organization and between the $120^{\circ}$ sector angle and angles of $60^{\circ}$ and $90^{\circ}(p<.05)$.

The total number of reversals (see Table 1) showed a significant effect of the organization factor $[F(2,90)=$ $42.71, p<.001]$. Newman-Keuls tests showed significant differences between the ambiguous organization and each of the other organizations $(p<.05)$. There were no effects of contrast $(F<1)$, orientation $[F(2,45)=$ $1.17, p<.31]$, or sector angle $[F(2,45)=1.59, p<$ $.21]$, nor were there any significant interactions.

The ambiguity ratios and other measures in Experiment 1 show that the factors of organization, contrast, and sector angle all affected figure-ground differentiation, but the most impressive determinant was the organization of the figure. Rubin (1921/1958) noted that a smaller enclosed area is usually seen as figure. With the present figure, response speeds were higher (and reaction times shorter) for the Cs organization when only the Cs were enclosed, and similarly for the enclosed keyhole. Our other measures-ratings, number of reversals, and perceived duration of each organization-showed a similar pattern of results. The ambiguous figures, in which both organizations were enclosed, increased reaction times dramatically, indicating indecision on the part of the subjects as to which region (Cs or keyhole) was seen as figure.

Luminance contrast has also been a significant factor in previous studies (Goldhammer, 1934; Harrower, 1936; Oyama, 1960). In the present experiment, luminance contrast between the two organizations-whether the Cs were black and the keyhole white, or vice versa-slightly but significantly favored the keyhole organization in the ambiguity ratios for response speed and ratings (see
Figure 4), but not for duration. When both organizations were white, the Cs were slightly favored in the above measures. These results suggest that the keyhole organization may be slightly stronger overall. Indeed, the grand mean of the ambiguity ratios for the combined measures of response speed, ratings, and reversals for all the figures was -0.02 . However, this value does not differ significantly from zero $(t<1)$.

Although sector angle has previously been found important (e.g., by Goldhammer, 1934; Künnapas, 1957; Oyama, 1960), this factor was less effective in the present experiment. However, a smaller sector angle in the keyhole did lead to reaction times and ratings favoring the keyhole organization, and larger sector angles contributed more to the Cs' being seen as figure. Thus, consistent with the literature cited above, the smaller the sector angle, the greater the tendency of an organization to be seen as figure.

All of the measures in Experiment 1 showed similar patterns of differences across the levels of the four factors. However, these measures were not highly correlated in all cases. Table 2 shows the correlations between all measures for the unambiguous Cs organization (above the diagonal) and for the unambiguous keyhole organization (below the diagonal). The correlations for the ambiguous organization (not shown) were essentially comparable. Reaction times, response speeds, and the ambiguity ratio for speed tended to be intercorrelated, and so did the measures involving ratings, reversals, and durations of perceived organizations. Thus, it appears that different measures may be responsive to different aspects of figure-ground relationships.

Ambiguity ratios provide a novel way of quantifying figure-ground organization. Like the Michelson contrast ratio for luminance, an ambiguity ratio is an index number varying between -1 and +1 , inclusive. Thus, the ambiguity ratio is a single index number that takes into account the strength of both possible organizations of an ambiguous figure. Another advantage of these ratios is that different measures of figural strength and ambiguity, such as response speeds, ratings, and perceived duration, can be compared readily.

Table 2

Correlations Between Measures for Unambiguous Cs Organization (Above Diagonal) and Unambiguous Keyhole Organization (Below Diagonal)

\begin{tabular}{|c|c|c|c|c|c|c|c|c|c|c|c|c|c|}
\hline & & RTC & RTK & SPC & SPK & ASP & RATC & RATK & ARAT & REV & DURC & DURK & ADUR \\
\hline ) & TC & & 15 & $9 \ddagger$ & .07 & -.25 & .02 & .17 & 15 & .04 & 6 & .06 & -.06 \\
\hline (sec) & F & $.28 *$ & & .06 & .7 & & & & & & & & .23 \\
\hline & $s$ & $-.96 \ddagger$ & .25 & & .07 & .12 & -.01 & & .1 & -.03 & .03 & .01 & .01 \\
\hline & & & $-.83 \ddagger$ & -.13 & & $-.96 \ddagger$ & -.19 & 0 & & .13 & & .25 & -.24 \\
\hline & & $.96 \ddagger$ & $.45 \ddagger$ & $.95 \ddagger$ & $-.30^{*}$ & & .18 & & .18 & -.10 & .24 & -.23 & .22 \\
\hline & & -.15 & .13 & & -.25 & .16 & & -.12 & $.37 \dagger$ & .04 & .00 & .01 & -.01 \\
\hline & & & -.13 & -.19 & 0 s & -.24 & -.14 & & $-.94 \ddagger$ & $.51 \ddagger$ & $-.57 \ddagger$ & $.54 \ddagger$ & $-.56 \ddagger$ \\
\hline & & .21 & 16 & & -.26 & .23 & $.97 \ddagger$ & $-.31 *$ & & $-.44 \ddagger$ & & $-.52 \ddagger$ & $.53 \ddagger$ \\
\hline & & 12 & -.03 & & -.10 & .05 & $.59 \ddagger$ & .06 & $.53 \ddagger$ & & $-.88 \ddagger$ & $.84 \ddagger$ & $-.87 \ddagger$ \\
\hline & & -.03 & & -.04 & -.21 & .01 & & .04 & $.57 \ddagger$ & $.86 \ddagger$ & & $-.96 \ddagger$ & $.98 \ddagger$ \\
\hline & & .06 & -.07 & & .22 & -.02 & $-.66 \ddagger$ & -.03 & $-.59 \ddagger$ & $-.92 \ddagger$ & $-.94 \ddagger$ & & $.99 \ddagger$ \\
\hline Ambiguity 1 & DUR & .03 & .09 & -.04 & -.21 & .01 & $.63 \ddagger$ & .04 & $.58 \ddagger$ & $.88 \ddagger$ & $.99 \ddagger$ & $-.96 \ddagger$ & \\
\hline
\end{tabular}

Note $-{ }^{*} p<.05$. $\dagger p<.01 . \ddagger p<.001$. 
The present Cs-keyhole figure is a highly ambiguous reversible figure. Some of the classic reversible figures, such as the vase-face (Rubin, 1921/1958) and wife-motherin-law (Boring, 1930) are less ambiguous, in that one organization tends to dominate. With the present figure, as noted earlier, the grand mean of all the ambiguity ratios for the combined measures of response speed, ratings, and durations was $-0.02(t<1)$. Thus, the Cs and keyhole organizations are essentially symmetrical-that is, nearly equally strong-and therefore the present figure is highly ambiguous.

\section{EXPERIMENT 2}

In the process of figure-ground organization, figural regions have previously been found to exhibit different properties than regions seen as background (Bridgeman, 1981; Julesz, 1978; Weitzman, 1963; Wong \& Weisstein, 1982). In the present Cs-keyhole figure, distances across the figural regions appear shorter than objectively equal distances measured across the ground. For example, in Figure 5A, distance AC, measured within the Cs, looks shorter than distance $\mathrm{AB}$, measured across the ground. In Figure 5B, distance $\mathrm{AB}$ lies within the keyhole figure, and looks shorter than distance $A C$, measured across the ground. In the ambiguous version of the figure, $5 \mathrm{C}$, these distances appear essentially to be equal. Experiment 2 was designed to measure these apparent distances, using a method of adjustment.

\section{Method}

Subjects. There were 12 male and 12 female subjects ranging in age from 18 to 32 years, with a mean of 20.96 .

Stimuli. The figures were $10 \mathrm{~cm}$ in diameter. The sector angles, the angles between the straight edges or lines, were $90^{\circ}$ in all cases (see Figure 5). Thus, distances $\mathrm{AB}$ and $\mathrm{AC}$ were $70.7 \mathrm{~mm}$. The Cs-keyhole figure was presented at all three levels of organization (Cs, keyhole, ambiguous), as in Figure 5. The figures were presented in horizontal and vertical orientation, so that distances across figure and ground would not be confounded with the horizontal-vertical illusion (Künnapas, 1957, 1959) or some variant of that effect (all of the stimuli in Figure 5 are oriented vertically). Luminance contrast between the $\mathrm{Cs}$ and keyhole organizations produced significant effects in Experiment 1, so all three levels of contrast (B/W, W/W, W/B) were included here as a between-subjects factor.

Apparatus. Figure 6 shows the subject's view of the apparatus. The front of the apparatus was black. The figures were presented

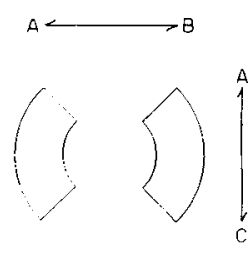

(A)

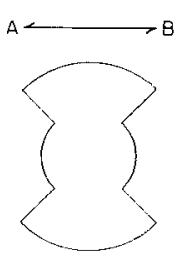

(B)

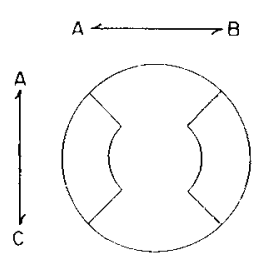

(C)
Figure 5. A: Cs organization; distance $A B$ is across ground, $A C$ is across figure. B: Keyhole organization; distance $\mathbf{A B}$ is across figure, $A C$ is across ground. C: Ambiguous organization; distance $\mathrm{AB}$ is across keyhole, $\mathrm{AC}$ is across Cs organization.

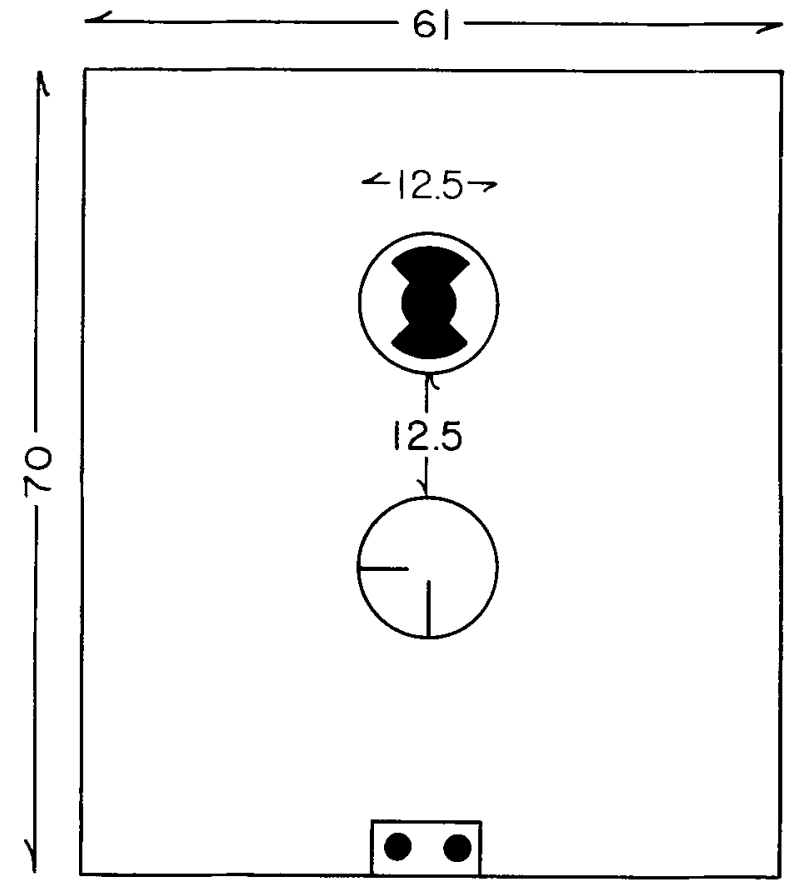

Figure 6. Subject's view of apparatus, with dimensions in centimeters. Horizontal and vertical comparison rods were never visible at the same time.

in a circular aperture $12.5 \mathrm{~cm}$ in diameter approximately at eye level, at a viewing distance of approximately $57 \mathrm{~cm}$. A second aperture of the same diameter, located $12.5 \mathrm{~cm}$ below the aperture described above (measured edge to edge), contained adjustable horizontal and vertical comparison rods $3 \mathrm{~mm}$ in diameter. The rods were black and were presented against a white background. By turning knobs, the subject adjusted the rods one at a time to indicate the perceived length of the distances across figure and ground. While each comparison rod was being adjusted, the other was out of sight. The displays were lighted by overhead fluorescent lights providing luminances of $67.9 \mathrm{~cd} / \mathrm{m}^{2}$ on the white portion of the figures, $4.7 \mathrm{~cd} / \mathrm{m}^{2}$ on the black portions, and $56.0 \mathrm{~cd} / \mathrm{m}^{2}$ on the white background of the comparison rods.

Procedure. To familiarize the subjects with the apparatus and procedures, three practice stimuli were shown to each subject in an individually randomized sequence (see Figure 7). The horizontal and vertical lines in the three practice stimuli were, respectively, 80 and $100 \mathrm{~mm}, 100$ and $100 \mathrm{~mm}$, and 100 and $80 \mathrm{~mm}$. The subjects were instructed to turn the appropriate knob with either hand, and to indicate when the adjustable comparison appeared equal to the distance being measured. Each horizontal and vertical distance was measured twice-first in an ascending trial (A), in which the comparison was initially set to a length about $20 \mathrm{~mm}$ shorter than the standard distance in the test stimulus, and then in a descending trial (D), in which the comparison was initially set about $20 \mathrm{~mm}$ longer than the standard distance. Orders of horizontal and vertical judgments were counterbalanced between subjects.

After the practice trials, the subjects were instructed to judge the horizontal and vertical distances across each of the $C s$ and keyhole figures, as in Figure 5. Four trials, counterbalanced in ADDA and DAAD order between subjects, were given for the horizontal distance measurements, and four trials were given in the same order for the vertical distances. The subjects had as much time as they needed to make their adjustments. Orders of horizontal and vertical judgments within figures were also counterbalanced between subjects. 


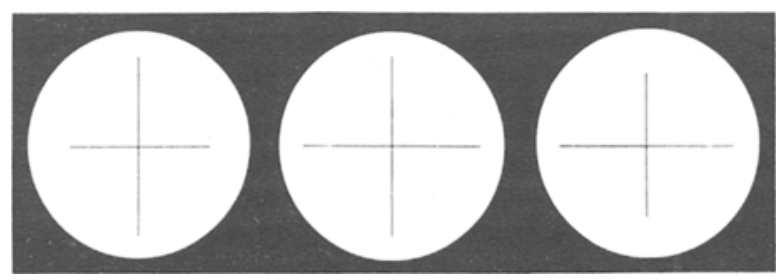

Figure 7. Practice stimuli.

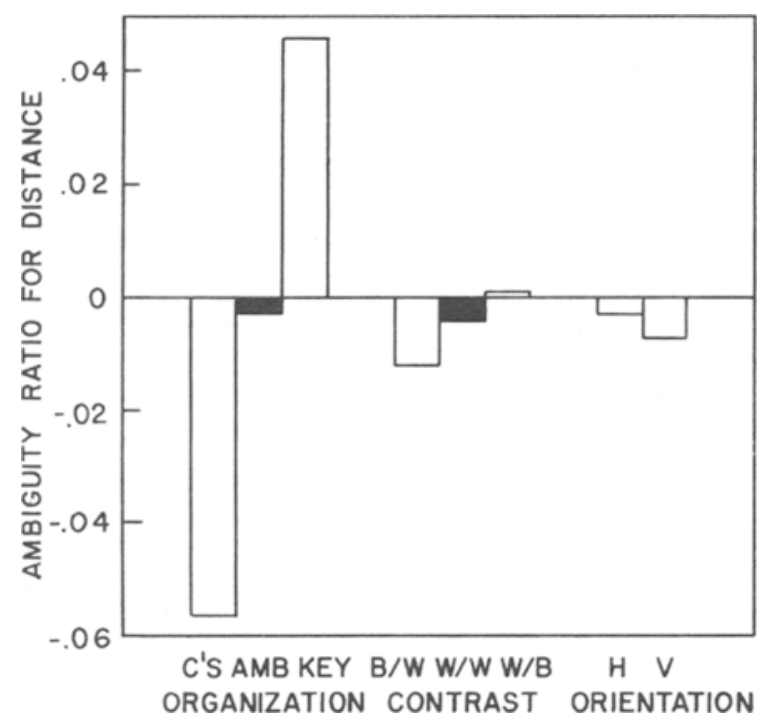

Figure 8. Results of Experiment 2.

The experimental design was a $3 \times 3 \times 2$ factorial, in which luminance contrast (B/W, W/W, W/B) was a between-subjects factor, and organization ( $\mathrm{Cs}$, ambiguous, keyhole) and orientation of figure (horizontal, vertical) were within-subjects factors. There were 8 subjects at each of the three levels of contrast, so each subject viewed six test stimuli (three levels of organization $\times$ two levels of figure orientation) in an individually randomized sequence.

\section{Results and Discussion}

For each subject, the four distance measures were averaged for each organization within each figure, and an ambiguity ratio for distance (ARD) was calculated. The ARD was found through substitution of the apparent distance in millimeters across the Cs and keyhole organizations, respectively, for $C$ and $K$ in Equation 1. Like the other ambiguity ratios in Experiment 1, the ARD had a possible range of -1 to +1 , with negative values indicating smaller apparent distances across the Cs organization, positive values indicating a smaller keyhole, and zero indicating equal distances across both organizations.

The ambiguity ratios were subjected to a $3 \times 3 \times 2$ mixed-design analysis of variance. The effect of organization was highly significant $[F(2,42)=36.10, p<.001]$, but there was no significant effect of contrast $[F(2,21)=$ $1.21, p>.25]$ or orientation $(F<1)$, and no interaction between factors. Newman-Keuls comparisons showed that all differences between levels of organization were significant $(p<.05)$. The mean ambiguity ratios are shown in Figure 8. The overall mean ambiguity ratio, averaged across all of the test figures, was -.005 , a value not significantly different from zero $(t<1)$.

Table 3 shows the means of the raw distance measures and ambiguity ratios for each level of the three factors. The apparent distances across the figures in the unambiguous Cs and keyhole organizations were, respectively, 62.42 and $63.85 \mathrm{~mm}$; these measures differed significantly from the objective value of $70.7 \mathrm{~mm}[t(23)=5.82$ and 4.86, $p<.001]$. The apparent distances across the ground in these organizations were, respectively, 70.27 and $70.05 \mathrm{~mm}$; neither of these measures differed significantly from the objective value (both $t s<1$ ).

As expected, when the Cs were seen as figure, the distance across these figural regions appeared smaller, and when the keyhole was seen as figure, the distance across this region appeared smaller. Also as expected, there were no significant differences in these distance judgments for the ambiguous figures. Vertical distances were predicted to appear longer than horizontal distances, due to the horizontal-vertical illusion (Künnapas, 1957, 1959), but the orientation factor was not significant.

\section{EXPERIMENT 3}

Experiment 3 was designed to assess the effects of perceptual set on apparent distance across figure and ground. The subjects were perceptually set to see one or the other region of the ambiguous stimulus as figure.

\section{Method}

Subjects. There were 12 male and 12 female subjects ranging in age from 18 to 31 years, with a mean of 21.46 .

Stimuli and Apparatus. The same stimuli, apparatus, and levels of luminance were used as in Experiment 2.

Table 3

Raw Distances (in mm) and Ambiguity Ratios in Experiment 2

\begin{tabular}{|c|c|c|c|c|c|c|c|c|c|c|}
\hline & \multirow{2}{*}{$\begin{array}{l}\text { Region } \\
\text { Measured }\end{array}$} & & \multicolumn{3}{|c|}{ Organization } & \multicolumn{3}{|c|}{ Contrast } & \multicolumn{2}{|c|}{ Orientation } \\
\hline & & & Cs & Ambig & Key & $\mathrm{B} / \mathrm{W}$ & $\mathrm{W} / \mathrm{W}$ & $\mathbf{W} / \mathbf{B}$ & $\mathbf{H}$ & V \\
\hline \multirow{2}{*}{ Distance $(\mathrm{mm})$} & Cs & $\begin{array}{l}\text { Mean } \\
S D\end{array}$ & $\begin{array}{r}62.42 \\
6.96 \\
\end{array}$ & $\begin{array}{r}64.23 \\
6.42 \\
\end{array}$ & $\begin{array}{r}70.05 \\
9.97\end{array}$ & $\begin{array}{r}65.68 \\
6.27\end{array}$ & $\begin{array}{r}63.62 \\
7.07 \\
\end{array}$ & $\begin{array}{r}67.40 \\
7.12 \\
\end{array}$ & $\begin{array}{r}65.39 \\
6.66 \\
\end{array}$ & $\begin{array}{r}65.74 \\
7.29 \\
\end{array}$ \\
\hline & Keyhole & $\begin{array}{l}\text { Mean } \\
S D\end{array}$ & $\begin{array}{l}70.27 \\
10.29\end{array}$ & $\begin{array}{r}64.70 \\
6.94\end{array}$ & $\begin{array}{r}63.85 \\
6.90\end{array}$ & $\begin{array}{r}67.26 \\
6.37\end{array}$ & $\begin{array}{r}64.18 \\
7.93\end{array}$ & $\begin{array}{r}67.37 \\
7.82\end{array}$ & $\begin{array}{r}66.39 \\
8.22\end{array}$ & $\begin{array}{r}66.15 \\
7.24\end{array}$ \\
\hline $\begin{array}{l}\text { Ambiguity ratio } \\
\text { for distance }\end{array}$ & & $\begin{array}{l}\text { Mean } \\
S D\end{array}$ & $\begin{array}{r}-.06 \\
.04\end{array}$ & $\begin{array}{l}.00 \\
.02\end{array}$ & $\begin{array}{l}.05 \\
.05\end{array}$ & $\begin{array}{r}-.01 \\
.02\end{array}$ & $\begin{array}{l}.00 \\
.02\end{array}$ & $\begin{array}{l}.00 \\
.01\end{array}$ & $\begin{array}{r}-.01 \\
.03\end{array}$ & $\begin{array}{l}.00 \\
.02\end{array}$ \\
\hline
\end{tabular}




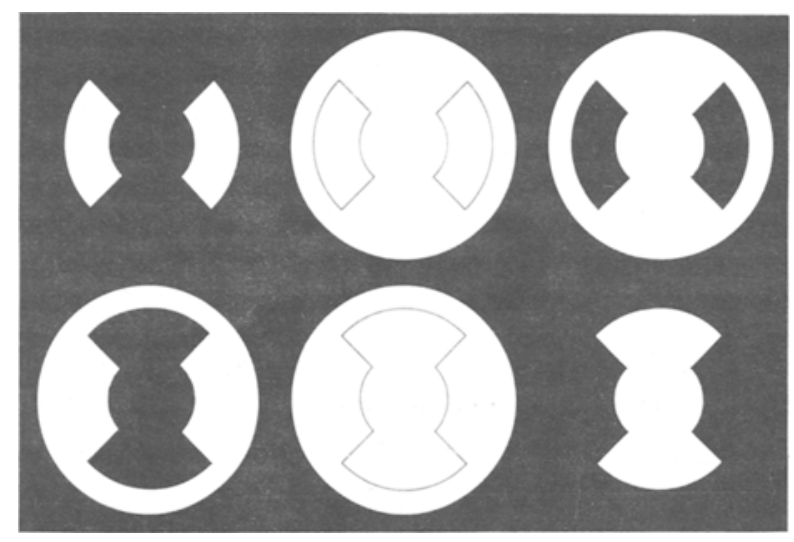

Figure 9. Stimuli used to induce perceptual sets in Experiment 3. Top: Cs organization. Bottom: Keyhole organization.

Procedure. The procedures were identical to those in Experiment 2, except in one respect. In Experiment 3, half of the subjects were given a perceptual set to see the $C s$ as figure, and half were set to see the keyhole as figure in the ambiguous stimulus. The Cs set was induced by having the subjects make distance judgments for three stimuli in which the Cs were unambiguous (see Figure 9, top row). The other subjects were set to see the keyhole by judging apparent distances in unambiguous keyhole stimuli (Figure 9, bottom row).

Two trials, counterbalanced in AD and DA order between subjects, were given for each horizontal and vertical distance measurement. There were two trials in Experiment 3, as opposed to the four in Experiment 2, because more stimuli were now presented. For each subject, the sequence of set-inducing stimuli was individually randomized. Each subject then made distance judgments for the ambiguous figure in which the Cs and keyhole organizations were both white $(\mathrm{W} / \mathrm{W})$, as in Figure 5C. The ambiguous figure was oriented horizontally and vertically, and the orders of these orientations were counterbalanced between subjects.

So that we could further assess the effectiveness of the set, after the apparent distances were measured, each subject rated the strength of the $\mathrm{Cs}$ and keyhole organizations in the ambiguous figure on the 11-point scale used in Experiment 1. Each subject first rated the organization to which he or she had been set and then rated the other organization. The figure was oriented horizontally and vertically for each subject, and orientation orders were counterbalanced between subjects.

\section{Results and Discussion}

The apparent distance measures in the unambiguous Cs and keyhole figures, made during the set-induction phase of the experiment, were converted to ambiguity ratios and subjected to a $2 \times 2 \times 3$ ANOVA. (Postset distance measures in the ambiguous figure were subjected to a separate analysis, described below.) The factors were organization (Cs, keyhole), orientation (horizontal, vertical), and luminance contrast $(B / W, W / W$, and $W / B)$. Organization was manipulated between subjects, and there were repeated measures on the last two factors. Thus, there were 12 subjects ( 6 males and 6 females) at each level of organization.

The organization factor produced a highly significant effect $[F(1,22)=60.02, p<.001]$, as in Experiment 2 , but the effects of contrast and orientation $(F<1)$, as well as all interactions, were nonsignificant. The mean ambiguity ratios for distance across the unambiguous $\mathrm{Cs}$ and keyhole stimuli measured during the set-induction phase of Experiment 3 are shown in Figure 10A (the other measures in that figure are described below).

A separate $2 \times 2$ ANOVA was necessary to determine the effects of the perceptual sets on the postset distance judgments in the ambiguous figure. Perceptual set (Cs, keyhole) was a between-subjects factor, and orientation (horizontal, vertical) was a within-subjects factor. The effect of perceptual set was significant $[F(1,22)=4.31$, $p<.05]$, but there was no significant effect of orientation, nor was there any significant interaction $(F<1)$. The postset distance measures in Figure 10A are the mean ambiguity ratios for the apparent distances measured across the $\mathrm{Cs}$ and keyhole regions in the ambiguous figure after the induction of the Cs and keyhole sets.

For the postset ratings of the ambiguous figure, made after the distance measurements, ambiguity ratios were subjected to a $2 \times 2$ ANOVA. The factors were perceptual set and orientation, with repeated measures on the
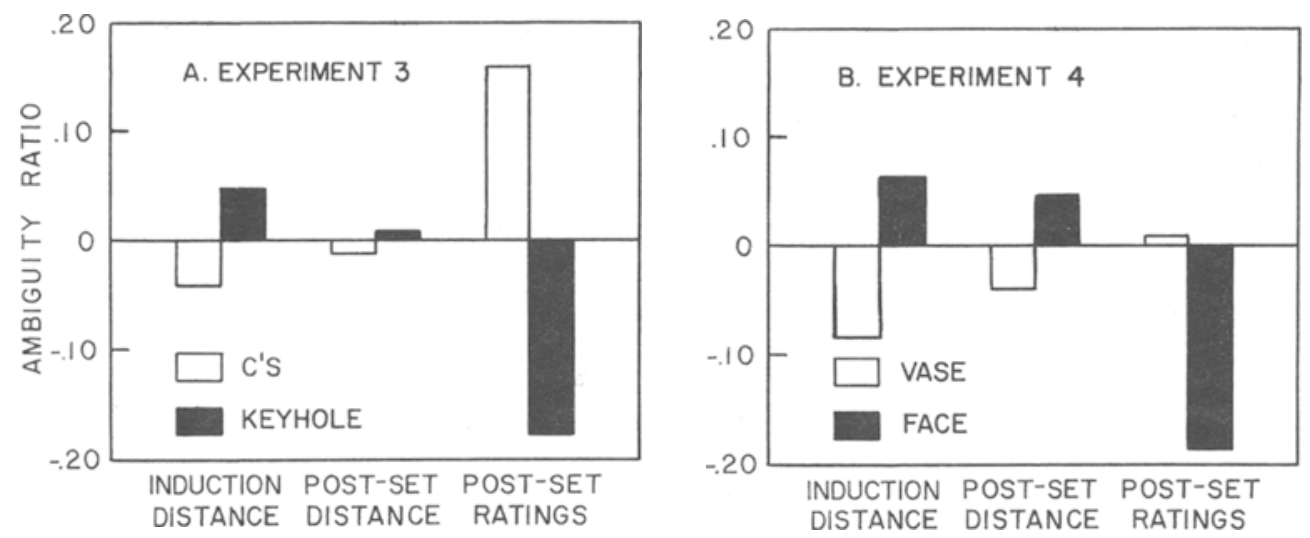

Figure 10. Results of Experiments 2 and 3. Induction distances are apparent distances across unambiguous Cs and keyhole regions, and across vase and face regions, in the induction phase of the experiments. Postset distances and ratings were measured after the induction of the perceptual sets. 
Table 4

Results of Experiments 3 and 4

Raw Scores and Derived Measures on Unambiguous Figures

During Induction of Perceptual Sets and on Ambiguous Figures After Set Induction

\begin{tabular}{|c|c|c|c|c|c|c|}
\hline \multirow[b]{2}{*}{ Experiment } & \multirow[b]{2}{*}{ Set } & \multirow[b]{2}{*}{ Region Measured } & & \multicolumn{2}{|c|}{ Distance (mm) } & \multirow{2}{*}{$\frac{\text { Rating }}{\text { Post }}$} \\
\hline & & & & Induction & Post & \\
\hline \multirow{6}{*}{3} & \multirow{3}{*}{ Cs } & Figure (Cs) & $\begin{array}{l}\text { Mean } \\
S D\end{array}$ & $\begin{array}{r}65.33 \\
4.29 \\
\end{array}$ & $\begin{array}{r}67.69 \\
4.42 \\
\end{array}$ & $\begin{array}{l}6.33 \\
1.60\end{array}$ \\
\hline & & Ground (keyhole) & $\begin{array}{l}\text { Mean } \\
S D\end{array}$ & $\begin{array}{r}71.49 \\
5.81 \\
\end{array}$ & $\begin{array}{r}69.48 \\
5.83 \\
\end{array}$ & $\begin{array}{l}4.71 \\
1.97 \\
\end{array}$ \\
\hline & & Ambiguity ratio & $\begin{array}{l}\text { Mean } \\
S D\end{array}$ & $\begin{array}{r}-.04 \\
.04 \\
\end{array}$ & $\begin{array}{r}-.01 \\
.02 \\
\end{array}$ & $\begin{array}{l}.16 \\
.31 \\
\end{array}$ \\
\hline & \multirow{3}{*}{ Keyhole } & Figure (keyhole) & $\begin{array}{l}\text { Mean } \\
S D\end{array}$ & $\begin{array}{r}62.47 \\
7.00 \\
\end{array}$ & $\begin{array}{l}66.58 \\
10.33 \\
\end{array}$ & $\begin{array}{l}7.54 \\
1.76 \\
\end{array}$ \\
\hline & & Ground (Cs) & $\begin{array}{l}\text { Mean } \\
S D\end{array}$ & $\begin{array}{r}68.66 \\
6.73 \\
\end{array}$ & $\begin{array}{l}67.75 \\
11.76 \\
\end{array}$ & $\begin{array}{l}5.29 \\
1.92 \\
\end{array}$ \\
\hline & & Ambiguity ratio & $\begin{array}{l}\text { Mean } \\
S D\end{array}$ & $\begin{array}{l}.05 \\
.02 \\
\end{array}$ & $\begin{array}{l}.01 \\
.03 \\
\end{array}$ & $\begin{array}{r}-.18 \\
.21 \\
\end{array}$ \\
\hline \multirow{6}{*}{4} & \multirow{3}{*}{ Vase } & Figure (vase) & $\begin{array}{l}\text { Mean } \\
S D\end{array}$ & $\begin{array}{r}61.27 \\
7.00 \\
\end{array}$ & $\begin{array}{l}62.72 \\
10.34 \\
\end{array}$ & $\begin{array}{l}7.31 \\
2.00 \\
\end{array}$ \\
\hline & & Ground (face) & $\begin{array}{l}\text { Mean } \\
S D \\
\end{array}$ & $\begin{array}{r}72.52 \\
7.03 \\
\end{array}$ & $\begin{array}{r}68.16 \\
8.83 \\
\end{array}$ & $\begin{array}{l}7.25 \\
1.84 \\
\end{array}$ \\
\hline & & Ambiguity ratio & $\begin{array}{l}\text { Mean } \\
S D\end{array}$ & $\begin{array}{r}-.08 \\
.04 \\
\end{array}$ & $\begin{array}{r}-.04 \\
.04 \\
\end{array}$ & $\begin{array}{l}.01 \\
.16 \\
\end{array}$ \\
\hline & \multirow{3}{*}{ Face } & Figure (face) & $\begin{array}{l}\text { Mean } \\
S D \\
\end{array}$ & $\begin{array}{r}64.19 \\
6.69 \\
\end{array}$ & $\begin{array}{r}63.48 \\
8.26 \\
\end{array}$ & $\begin{array}{l}7.34 \\
1.74 \\
\end{array}$ \\
\hline & & Ground (vase) & $\begin{array}{l}\text { Mean } \\
S D\end{array}$ & $\begin{array}{r}73.34 \\
8.12 \\
\end{array}$ & $\begin{array}{r}69.61 \\
8.49 \\
\end{array}$ & $\begin{array}{l}5.09 \\
1.56 \\
\end{array}$ \\
\hline & & Ambiguity ratio & $\begin{array}{l}\text { Mean } \\
S D\end{array}$ & $\begin{array}{l}.07 \\
.04\end{array}$ & $\begin{array}{l}.05 \\
.04\end{array}$ & $\begin{array}{r}-.19 \\
.18\end{array}$ \\
\hline
\end{tabular}

latter factor. Perceptual set was significant $[F(1,22)=$ $9.62, p<.001]$, but orientation was not $(F<1)$. The results here are consistent with the apparent distance measurements, but the ratings show the effects of set more strongly (see Figure 10A).

Table 4 shows the raw distance measures, raw ratings, and ambiguity ratios for Experiment 3. For the induction measures, made during the induction of the perceptual sets, the apparent distances across the figures in the unambiguous Cs and keyhole organizations were, respectively, 65.33 and $62.47 \mathrm{~mm}$. Both measures differed significantly from the objective value of $70.7 \mathrm{~mm}[t(11)=$ 4.34 and 4.07, $p<.01]$. The apparent distances across the grounds in these organizations were, respectively, 71.49 and $68.66 \mathrm{~mm}$, neither of which differed significantly from the objective value $[t(11)=0.47$ and 1.05$]$. Thus, the present measures of apparent distance are comparable to the results of Experiment 2.

The results of Experiment 3 provided further evidence that distances across figures appear smaller than distances across background regions. In addition, perceptual sets induced by judging distances across unambiguous $\mathrm{Cs}$ and keyhole figures influenced subsequent measurements of apparent distance and also influenced judgments of the perceived strength of these organizations in ambiguous figures.

\section{EXPERIMENT 4}

Experiment 4 was conducted to assess figure-ground relationships in some variants of Rubin's classic vase-face figure, presented in real and subjective contours. Rubin's figure was chosen because it could be easily produced in subjective contours. Distances across figure and ground were measured, and the effects of perceptual sets were also assessed. Experiment 4, which was essentially a replication of Experiment 3, was designed in part to test the generality of the previous results.

\section{Method}

Subjects. There were 16 male and 16 female subjects ranging from 18 to 32 years in age, with a mean of 20.34 .

Stimuli and Apparatus. The stimuli were the variants of the classic vase-face figure shown in Figure 11 . All stimuli were $10 \mathrm{~cm}$ in diameter and were presented in a vertical orientation. The apparent distances measured here, $\mathrm{AB}$ and $\mathrm{AC}$ in Figure 11, corresponded with the distances measured in the previous experiments (see Figure 5). These objective distances were $70.7 \mathrm{~mm}$. The same apparatus was used in Experiments 2 and 3.

Procedure. The measurement procedures were the same as those in Experiment 3. Half the subjects were given a perceptual set to see the vase as figure, and half were set to see the faces as figure in the ambiguous organization. Each set was induced by having the subjects judge the apparent distances across figure and ground (see distances $\mathrm{AB}$ and $\mathrm{AC}$ in Figure 11) in unambiguous vase or face 


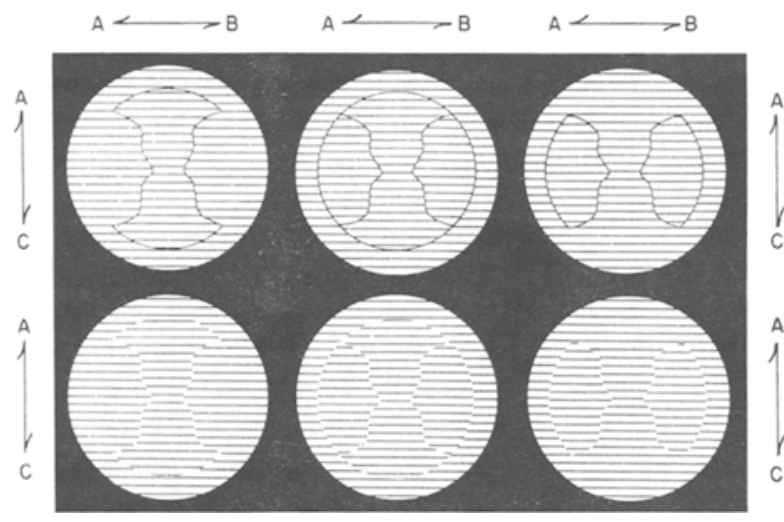

Figure 11. Stimuli in Experiment 4. Vase, ambiguous, and face organizations in real contours (top) and in subjective contours (bottom).

figures in real and subjective contours. Perceptual set (vase, face) was a between-subjects factor, and kind of contour (real, subjective) was a within-subjects factor.

After the set-induction phase of Experiment 4, the subjects judged the apparent distance across the two organizations in the ambiguous vase-face figures in real and subjective contours. The subjects then rated the apparent strength of these organizations in the ambiguous figures.

\section{Results and Discussion}

As in Experiments 2 and 3, an ambiguity ratio for distance was utilized in the present experiment. For each subject, the apparent distance measures were averaged for each organization for the two trials. The ARD was found through substitution of the apparent distance in millimeters across the vase and faces organizations, respectively, for $C$ and $K$ in Equation 1. Negative values of the ARD indicated smaller apparent distances across the vase organization, positive values indicated smaller faces, and zero indicated equal distances across both organizations.

The ARDs for the unambiguous vase and face stimuli in the set-induction phase of Experiment 4 were subjected to a $2 \times 2$ ANOVA. The factors were organization (vase, face) and kind of contour (real, subjective), with repeated measures on the latter factor. Organization produced a significant effect $[F(1,30)=106.81, p<.001]$, but kind of contour and the set $\times$ contour interaction were not significant $[F(1,30)=3.47, p<.07$, and $F(1,30)=$ $1.84, p<.18$, respectively]. The induction measures in Figure 10B show the mean ambiguity ratios for distances across the unambiguous vase and face organizations measured during the set-induction phase of Experiment 4 .

An additional ANOVA was done to assess the effects of the perceptual sets on the postset distance judgments in the ambiguous figure. Perceptual set (vase, face) was a between-subjects factor, and kind of contour (real, subjective) was a within-subjects factor. The effect of perceptual set was significant $[F(1,30)=33.06, p<.001]$, but there was no significant effect of kind of contour $[F(1,30)=1.56, p<.22]$, nor was there a set $\times$ con- tour interaction $(F<1)$. The postset measures for distance in Figure 10B show the ambiguity ratios for apparent distances across the Cs and keyhole organizations in the ambiguous figures, measured after the induction of the perceptual sets.

Another ANOVA was done to assess the effects of the perceptual sets on the rated strength of the vase and face portions of the ambiguous figures. Perceptual set and kind of contour produced significant effects $[F(1,30)=10.02$, $p<.01$, and $F(1,30)=5.58, p<.05$, respectively]. The set $X$ contour interaction was not significant $(F<1)$. Figure 10B shows the mean ambiguity ratios for the postset ratings. Table 4 shows the raw distance measures, ratings, and ambiguity ratios.

The present results demonstrate the generalizability of the findings of Experiments 2 and 3-that is, distances across figures look smaller than distances across ground. In addition, the effects of perceptual sets were more striking in the vase-face figure than in the Cs-keyhole figure in Experiment 3. There were no significant differences between apparent distances in real and subjective contours. In this respect, the present results are consistent with those of earlier studies, in which real and subjective contours produced similar though not identical effects (e.g., Bradley \& Petry, 1977; Farné, 1968; Gregory, 1972; Walker \& Shank, 1987). However, real contours were judged stronger and less ambiguous, which also was consistent with others' findings (Halpern \& Warm, 1980; Pomerantz, Goldberg, Golder, \& Tetewsky, 1981; A. T. Smith \& Over, 1975, 1979).

\section{GENERAL DISCUSSION}

A possible physiological explanation of the reversibility of ambiguous figures derives from Köhler and Wallach's (1944) satiation theory. According to this theory, a particular organization remains dominant until its neural substrate reaches a critical level of satiation, or fatigue. At that point, the rival organization becomes dominant and remains so until eventually it too becomes critically satiated, and gives way to the reappearance of the previous organization, now refreshed (e.g., see Carlson, 1953; Hochberg, 1950; Köhler \& Wallach, 1944; Rock, 1975).

Satiation and adaptation processes appear likely to be involved in the reversibility of ambiguous figures, but it is unclear whether these processes play any direct role in determining the apparent distance across regions of figure and ground. We now consider several possible explanations of our observed distance effects: (1) differences in the apparent depth of figure and ground, (2) an aspect of the Müller-Lyer illusion, (3) a feature-detector model of contour attraction, (4) a natural set or predisposition to see a figure as smaller, and (5) framing effects.

A figure is usually seen as closer to the observer than the background, which tends to recede in depth. Therefore, the distance across a figural region would tend to appear smaller than the same distance across the back- 
ground, in accordance with Emmert's law and the size-distance invariance hypothesis (Boring, 1940; Coren, 1972; Epstein, Park, \& Casey, 1961).

An aspect of the Müller-Lyer illusion may also contribute to the smaller apparent distances across figures. Consider the distance across the keyhole figure in the vertical orientation, distance $\mathrm{AB}$ in Figure 5B. The lines enclosing this distance have some of the characteristics of the inward-bending fins of the Müller-Lyer illusion. Two such fins are present at each end of distance $A B$, perhaps reducing this apparent distance. Now consider distance $\mathrm{AC}$ in Figure 5B. At each end of this distance, there is an inward- and an outward-bending fin, so the MüllerLyer illusion should have little or no effect on distance AC. Similar arguments also apply to the distance across the $\mathrm{Cs}$ in Figure 5A. In the ambiguous figure, 5C, each end of distance $A B$ and $A C$ has one outward-bending and two inward-bending fins. Thus, the Müller-Lyer illusion should have essentially no effect on apparent distances in the ambiguous figure.

In passing, we note that our figures also produce a variety of the Poggendorff illusion (Coren \& Girgus, 1978; Robinson, 1972). In Figure 5A, the oblique lines bounding the tops of the Cs appear displaced upward in relation to the collinear oblique lines bounding the bottoms of the Cs. A similar effect occurs in the unambiguous keyhole in Figure 5B, but the effect appears much reduced in the ambiguous figure in $5 \mathrm{C}$. We have made no quantitative measures of these Poggendorff variants.

A feature-detector model proposed to account for contour attraction, or assimilation, in the Bourdon illusion (Walker \& Shank, 1987) may also be related to the present distance effects. In Figure 5A, if the lines defining the Cs were attracted, or assimilated, toward each other in the vicinity of points $A, B$, and $C$, then distance $A B$ would appear shorter than $\mathrm{AC}$, as was the case. An analogous argument also applies to the keyhole organization in Figure 5B. In the ambiguous figure, 5C, contour attraction would not result in any differential effects on these apparent distances.

However, the above model fails to account for one aspect of the present results. In the Bourdon illusion, edges, as opposed to lines, showed greater attraction effects, as the model predicts (Walker \& Shank, 1988). In Figure 9 (bottom), the contours defining the black and white keyholes are edges, as opposed to the lines defining the outline keyhole. Thus, we should expect greater attraction between these edges, and greater shortening of the apparent distance across these figures in comparison with the outline figure, but we found no such difference. The feature model of the Bourdon illusion is therefore only partially successful in accounting for our present observations.

The relative physical size of figures and their backgrounds may play a role in our observed distance effects. Because figural regions are likely to be physically smaller and more enclosed than their backgrounds (Koffka, 1935; Rubin, 1921/1958), it may be that the observer develops a natural set or predisposition to see a distance across a figure as smaller than an equal distance across a ground region.

Framing effects (Fellows, 1968; Künnapas, 1955) have been shown to influence distance judgments. Depending on the framing ratio-that is, the ratio of the size of a frame to the size of a focal distance to be judged-the focal distance may be overestimated for small framing ratios and underestimated for large ratios. In the unambiguous $\mathrm{Cs}$ organization, the distance across the Cs is framed, and the distance across the ground is not. Similarly, in the unambiguous keyhole organization, the distance across the keyhole is framed. When the ambiguous figure is observed, the distances across the Cs and the keyhole organization are both framed, thus perhaps neutralizing any framing effects. Although framing effects may play some role in our observed distance effects, the precise nature of that role-if any-remains to be determined.

Whatever the mechanism or mechanisms underlying our observed distance effects, the perceptual sets induced in Experiments 3 and 4 indicate the operation of cognitive factors (see also Epstein \& De Shazo, 1961; Epstein \& Rock, 1960). The particular region of an ambiguous stimulus that tended to be seen as figure-Cs, keyhole, vase, or faces-was determined by the set that had been induced. The organizations that subjects were set to see were rated stronger, and distances across these figural organizations appeared shorter than distances across the ground.

To summarize, several processes may contribute to the smaller apparent distance across figures in comparison with objectively equal distances across backgrounds: (1) the apparent forward displacement of a figure in depth, working in accordance with Emmert's law and the size-distance hypothesis; (2) a manifestation of the Müller-Lyer illusion; (3) contour attraction or assimilation involving feature detectors; (4) a naturally induced set to see figures as smaller than their backgrounds; and (5) framing effects. The first two explanations appear to be the most promising.

The fact that apparent distances in ambiguous figures were susceptible to induced sets implicates the operation of cognitive processes. The observed effects occurred in a novel Cs-keyhole reversible figure, and also in Rubin's classic vase-face figure presented in real and subjective contours. Thus, the observed effects are of some generality.

\section{REFERENCES}

Ayllon, T., \& SOMmer, R. (1956). Autism, emphasis and figure-ground perception. Journal of Psychology, 41, 163-176.

Boring, E. G. (1930). A new ambiguous figure. American Journal of Psychology, 42, 444-445.

Boring, E. G. (1940). Size constancy and Emmert's Law. American Journal of Psychology, 53, 293-295.

Bradley, D. R., \& Petry, H. M. (1977). Organizational determinants of subjective contour: The subjective Necker cube. American Journal of Psychology, 90, 253-262.

Bridgeman, B. (1981). Cognitive factors in subjective stabilization of the visual world. Acta Psychologica, 48, 111-121. 
Carlson, V. R. (1953). Satiation in a reversible perspective figure. Journal of Experimental Psychology, 45, 442-448.

Coren, S. (1972). Subjective contours and apparent depth. Psychological Review, 79, 359-367.

COREN, S., \& Girgus, J. S. (1978). Seeing is deceiving: The psychology of visual illusions. Hillsdale, NJ: Erlbaum.

EPstein, W., \& De Shazo, D. (1961). Recency as a function of perceptual oscillation. American Journal of Psychology, 74, $215-223$.

Epstein, W., PARK, J., \& CASEY, A. (1961). The current status of the size-distance hypothesis. Psychological Bulletin, 58, 491-514.

EPSTEIN, W., \& Rock, I. (1960). Perceptual set as an artifact of recency. American Journal of Psychology, 73, 214-228.

FARNÉ, M. (1968). Alcune osservazioni con linee virtuali e margini quasi percettivi. Bolletino della Società Italiana di Biologia Sperimentale, 44, 1613-1616.

Fellows, B. J. (1968). The reverse Müller-Lyer illusion and 'enclosure.' British Journal of Psychology, 59, 369-372.

Gerow, J. (1986). Psychology: An introduction. Glenview, IL: Scott, Foresman.

Goldhammer, H. (1934). The influence of area, position, and brightness in the visual perception of a reversible configuration. American Journal of Psychology, 46, 189-206.

GrEgory, R. L. (1972). Cognitive contours. Nature, 238, 51-52.

HALPERN, D. F., \& WARM, J. S. (1980). The disappearance of real and subjective contours. Perception \& Psychophysics, 28, 229-235.

HARROWER, M. R. (1936). Some factors determining figure-ground articulation. British Journal of Psychology, 26, 407-424

HochBeRg, J. (1950). Figure-ground reversal as a function of visual satiation. Journal of Experimental Psychology, 40, 682-686.

JuLESz, B. (1975). Experiments in the visual perception of texture. Scientific American, 232(4), 34-43.

JULEsz, B. (1978). Perceptual limits of texture discrimination and their implications to figure-ground separation. In E. L. J. Leeuwenberg \& H. F. J. M. Buffart (Eds.), Formal theories of visual perception (pp. 205-216). New York: Wiley.

JuLesz, B. (1981). Textons, the elements of texture perceptions and their interactions. Nature, 290, 91-97.

KLYMENKo, V., \& Weisstein, N. (1986). Spatial frequency differences can determine figure-ground organization. Joumal of Experimental Psychology: Human Perception \& Performance, 12, 324-330.

KOFFKA, K. (1935). Principles of Gestalt psychology. London: Routledge and Kegan Paul.

Köhler, W., \& Whlach, H. (1944). Figural after-effects. Proceedings of the American Philosophical Society, 88, 269-357.

KüNNAPAS, T. M. (1955). Influence of frame size on apparent length of line. Joumal of Experimental Psychology, 50, 168-170.

KüNNAPAS, T. M. (1957). Experiments on figural dominance. Journal of Experimental Psychology, 53, 31-39.

KüNNAPAS, T. M. (1959). The vertical-horizontal illusion in the artificial visual field. Journal of Psychology, 47, 41-48.
Lindauer, M. S., \& Lindauer, J. G. (1970). Brightness differences and the perception of figure-ground. Journal of Experimental Psychology, 84, 291-295.

OyAma, T. (1960). Figure-ground dominance as a function of sector angle, brightness, hue, and orientation. Journal of Experimental Psychology, 60, 299-305.

Pomerantz, J. R., Goldberg, D. M., Golder, P. S., \& Tetewsky, S. (1981). Subjective contours can facilitate performance in a reactiontime task. Perception \& Psychophysics, 29, 605-611.

REgan, D., \& BeVERLEY, K. T. (1984). Figure-ground segregation by motion contrast and by luminance contrast. Joumal of the Optical Society of America, 1, 433-442.

RoBINSON, J. O. (1972). The psychology of visual illusion. London: Hutchinson.

Rock, I. (1975). An introduction to perception. New York: Macmillan.

Rubin, E. (1958). Figure and ground. In D. C. Beardslee \& M. Wertheimer (Eds.), Readings in perception (pp. 194-203). Princeton, NJ: D. van Nostrand. (Original work published by Gyldendal, Copenhagen, 1921)

SCHAFER, R., \& MURPHY, G. (1943). The role of autism in a visual figure-ground relationship. Journal of Experimental Psychology, 32, 335-343.

Sekuler, R., \& Blake, R. (1985). Perception. New York: Knopf.

SMITH, A. T. \& OVER, R. (1975). Tilt aftereffects with subjective contours. Nature, 257, 581-582.

SMITH, A. T., \& Over, R. (1979). Motion aftereffect with subjective contours. Perception \& Psychophysics, 25, 95-98.

SMITH, D. E. P., \& HochberG, J. E. (1954). The effect of "punishment' (electric shock) on figure-ground perception. Journal of Psychology, 38, 83-87.

WALKer, J. T., \& SHANK, M. D. (1987). The Bourdon illusion in subjective contours. Perception \& Psychophysics, 42, 15-24.

WALKER, J. T., \& ShaNk, M. D. (1988). Real and subjective lines and edges in the Bourdon illusion. Perception \& Psychophysics, 43, 475-484.

Weitzman, B. (1963). A threshold difference produced by a figureground dichotomy. Joumal of Experimental Psychology, 66, 201-205.

WEVER, E. G. (1927). Figure and ground in the visual perception of form. American Journal of Psychology, 38, 194-226.

WoNG, E., \& WeISSTEIN, N. (1982). A new perceptual context superiority effect: Line segments are more visible against a figure than against a ground. Science, 218, 587-589.

ZUSNE, L. (1970). Visual perception of form. New York: Academic Press.

(Manuscript received July 15, 1988; revision accepted for publication February 1, 1989.) 